\title{
Aged American Cheddar Cheese as Source of Protein Derived Compounds that Modulate Obese Mice Fecal Bacteria and Colon Inflammation In Vitro
}

\author{
Luis Condezo-Hoyos ${ }^{1,3}$, Giuliana D Noratto ${ }^{1,2 *}$ \\ ${ }^{1}$ School of Food Science, Washington State University \\ ${ }^{2}$ Current address: Department of Nutrition and Food Science, Texas A\&M University \\ ${ }^{3}$ Current address: Faculty of Medicine, Universidad Autónoma de Madrid, Spain
}

Received: September 13, 2016; Accepted: October 26, 2016; Published: November 08, 2016

*Corresponding author: Dr. Giuliana Noratto, Ph.D, Department of Nutrition and Food Science, Texas A\&M University. 1500 Research PKWY, Centeq A, Room 220D, College Station, TX 77845. Fax: 979862 4056; Tel: 979-571-0272; E-mail: gnoratto@tamu.edu

\begin{abstract}
Intestinal bacteria are key component in obesity and obesityinduced inflammation that leads to chronic diseases. Lactobacillus helveticus, a highly autolytic and proteolytic strain, has been associated with dairy products with health benefits.

We investigated protein changes in American cheddar cheese manufactured with Lactobacillus helveticus (Cougar Gold brand, CG) during ripening, and their potential as modulators of fecal bacteria and colon Reactive Oxygen Species (ROS) in vitro.

Results confirmed that casein-derived products and proteins/peptides released after In Vitro Digestion (IVD) shifted DNA abundances of Enterobacteriaceae, Enterococcus, and Bifidobacterium spp. in obese mice feces to resemble lean mice. CG fecal fermentation metabolites protected human colon fibroblast CCD-18Co cells against production of ROS.

Overall, proteins in aged cheese might help to improve obese fecal bacteria balance and protect against obesity-induced colon inflammation. Further in vivo studies are needed to validate these findings and to confirm the intestinal beneficial value of ripened cheese.

Keywords: Cheese Proteins; Cheese Ripening, Obese Fecal Bacteria, Colon Inflammation
\end{abstract}

\section{Abbreviations}

CG: Cougar Gold brand; ROS: Reactive oxygen species; IVD: In vitro digestion; SLAB: Starter lactic acid bacteria; NSLAB: Nonstarter lactic acid bacteria; MRPs: Maillard reaction products; AGEs: Advanced glycation end-products; PCR: Polymerase chain reaction; SCFAs: Short-chain fatty acids; RFU: Relative fluorescence units; PCA: Principal component analysis;

\section{Introduction}

Proteolysis of cheese caseins can be attributed to enzymes from milk and coagulant, as well as proteolytic activity of Starter Lactic Acid Bacteria (SLAB) and Non-Starter Lactic Acid Bacteria (NSLAB). In addition, cheese produced with Lactobacillus helveticus as adjunct culture has been reported to produce novel flavors, to improve acceptability of reduced-fat cheddar cheese, and to increase concentrations of low molecular weight peptides due to its high proteolytic activity and ability to autolyze [1]. The use of the L. helveticus strain as an adjunct to traditional starter cultures has been studied in cheese ripening. Results have shown that it produces a strongly flavored cheese within a relatively short period (2 mo). The main feature of the adjunct culture $\mathrm{L}$ helveticus is its ability to autolyze during cheese ripening which contributes to improved flavor [1]. This is evidenced by the release of intracellular enzymes such as d-lactate dehydrogenase and prolinase [2].

In addition, peptides produced by L. helveticus have been demonstrated to possess biological activity as angiotensin converting enzyme inhibitors in fermented dairy products. L. helveticus has genes responsible for key metabolic functions such as proteolysis, lipolysis, and cell lysis.

Thus, some health benefits of milk fermented with L. helveticus include the blood pressure lowering effect in a human clinical trial associated with the peptides-induced inhibition of Angiotensin Converting Enzyme (ACE), a molecule that promotes vasoconstriction. A study examined the effects of 8 mo ripened Gouda-type cheese produced using L. helveticus in addition to the starter culture bacteria. Results showed the suppression of abdominal adipose tissue accumulation in rats fed freeze dried cheese on a $20 \%$ fat diet compared with rats given butter oil and casein in isocaloric diet [3]. The cheese diet also led to changes in metabolic syndrome markers and inflammation such as reduction of serum cholesterol, triglycerides, very low density lipoprotein, low-density lipoprotein, and reduction on production of 
adiponectin from abdominal adipose tissue. However, the effects exerted by cheese consumption in preventing the development of obesity-related metabolic disorders might be attributed to the combination of SLAB and the peptides and fat components formed during the cheese ripening process.

Cheese ripening results in production of nucleophilic amino groups that react with carbonyl groups of reducing sugars and their degradation products through a series of non-enzymatic browning reactions called Maillard reactions. The series of reaction pathways that occur during cheese ripening are accompanied by decrease in reducing sugars, non-enzymatic browning, and the formation of early and advanced Maillard Reaction Products (MRPs) as described in detail [4].

The controversies around human health effects of MRPs have been extensively reviewed [5]. Harmful effects of dietary MRPs are related to their ability to promote glycation in vivo and to contribute to the progression of diabetes, cardiovascular complications and Alzheimer's disease. The pathophysiological state in diabetes increase Advanced Glycation End-products (AGEs) load due to the impaired renal function and limited urine excretion. This indicates that, diabetic subjects are more sensitive to dietary MRPs, especially if they don't keep blood glucose levels under control. This became evident when intake of severely heattreated foods by healthy subjects did not increase endogenous levels of AGEs nor impaired renal function compared to the intake of a diet with fruit and vegetables [6]. On the other hand, the health benefits of MRPs are linked to their antioxidant, chemo preventive, and antimutagenic activities as reviewed in vitro and in vivo [5, 7]. Even though the effects of MRPs reported in the literature may not translate to humans, the antioxidant and chemo preventive activities of MRPs are associated to the induction of phase II detoxifying enzymes due to their ability to bind to an antioxidant responsive element. MRPs' antimutagenic activity is related to their ability to bind to heterocyclic aromatic amines and other mutagens, thus preventing their digestion, absorption, and harmful physiological effects. In addition, glycated proteins are more resistant to gastrointestinal enzymes and can reach the lower gastrointestinal tract where they have the potential to modulate the physiology of the intestinal ecosystem [8, 9]. Less complex MRPs structures, which are preferentially produced in the presence of water and during shorter heating times, have shown to promote Bifidobacteria growth and the production of short chain fatty acids in a fermenter containing human fecal bacteria [5].

Our aim was to investigate how the ripening process influences the content of protein derived bioactive compounds in cheddar cheese produced with L. helveticus as adjunct culture and their potential to modulate gut bacteria communities and colon oxidative stress levels in vitro.

\section{Materials and Methods}

\section{Chemicals}

Acetone, glycerol, hydrochloric acid, methanol, sodium potassium tartrate and Tris base were purchased from Fisher
(Pittsburgh, PA). Acetic acid, propanol and sodium hydroxide were acquired from JT Baker (Center Valley, PA). Bacterial growth media and supplements were obtained from BD (Franklin Lakes, NJ). The remaining chemicals and reagents were obtained from Sigma-Aldrich Co. Ltd. (Saint Louis, MO). All reagents were ACS grade, $\geq 99 \%$ purity. Primers for PCR were acquired from Integrated DNA Technology (San Diego, CA).

\section{Cheese manufacture}

The American type cheddar cheese Cougar Gold brand (CG) was manufactured in production scale at the Washington State University (WSU) creamery, according to the standard cheddar cheese making procedures as previously reported [10]. Briefly, the bacterial starter cultures Lactococcus lactis ssp. lactis, Lactococcus lactis ssp. cremoris were provided frozen by Chr. Hansen's Laboratory Inc. (Milwaukee, WI). The Lactococcus cultures were grown in Delvolac LS-6 internally buffered starter medium (DSM Food Specialists B.V., Netherlands), and were inoculated at a concentration range of $0.31 \%$ to $0.47 \%$ $\left(10^{10}\right.$ colony forming units (cfu $\mathrm{mL}^{-1}$ ) in milk. The Lactobacillus helveticus WSU19 adjunct culture maintained in liquid nitrogen at the WSU Creamery, was activated in sterile homogenized milk up to $10^{9} \mathrm{cfu} \mathrm{mL}^{-1}$, and inoculated in a ratio of $45 \mathrm{~mL} / 24.5 \mathrm{Kg}$ of milk. Curd was pressed overnight $\left(38 \times 10^{4} \mathrm{~Pa}\right.$ pressure on dial and $4.6 \times 10^{4} \mathrm{~Pa}$ pressure on cheese), vacuum sealed in cans and maintained at $7^{\circ} \mathrm{C}$ for ripening for up to $24 \mathrm{mo}$. The samples were taken from batches produced under same conditions (starter culture, milk, and processing), and maintained under inventory by the WSU creamery, to keep ripening time as the only variable among samples. CG cheese samples on day 0 of ripening had $38.05 \%$ moisture, $1.55 \%$ salt, $35.15 \%$ fat, and $\mathrm{pH} 4.98$ analyzed following official standards methods.

\section{L. helveticus counting}

For selective growth of mesophilic lactobacilli (L. helveticus) and inhibition of Lactococcus lactis ssp. cremoris, and Lactococcus lactis ssp. Lactis used as SLAB, cheese samples (10 g) were homogenized with $90 \mathrm{~mL}$ of peptone saline solution in stomacher Lab-Blender 400 Circulator (Seward Medical, London, UK) for approximately $3 \mathrm{~min}$ and analyzed by plating appropriate tenfold dilutions onto MRS agar adjusted to $\mathrm{pH} 5.4$ and incubated for $48 \mathrm{~h}$ at $37^{\circ} \mathrm{C}$ [11]. Results were expressed as L. helveticus cfu $\mathrm{g}^{-1}$ of cheese.

\section{Reducing sugars}

Reducing sugars were extracted from cheese by homogenizing $5 \mathrm{~g}$ of cheese samples with $10 \mathrm{~mL}$ of phosphate buffer $(10$ $\mathrm{mmol} / \mathrm{L}, \mathrm{pH} 7.0$ ) and centrifugation $(5000 \mathrm{~g}$ for 15 minutes at $4^{\circ} \mathrm{C}$ ) to remove fat. The supernatant was extracted with 4 volumes of chloroform: methanol (2:1 vol/vol) and centrifuged at $15000 \mathrm{~g}$ for $15 \mathrm{~min}\left(4^{\circ} \mathrm{C}\right)$ [12]. Reducing sugars were quantified in supernatant by the 3,5-dinitrosalicylic acid (DNS) assay [13]. Briefly, $30 \mu \mathrm{L}$ volume of the glucose standards $(0.5,1.0,1.5$ and $2.0 \mathrm{mg} / \mathrm{mL}$ ) or samples diluted in $0.1 \mathrm{~mol} / \mathrm{L}$ sodium acetate buffer $\mathrm{pH} 5.5$ were added to $60 \mu \mathrm{L} 1 \%$ DNS reagent, heated at $95^{\circ} \mathrm{C}$ for 5 min, and cooled to $20^{\circ} \mathrm{C}$ in a T100 Thermal cycler (Bio-Rad, 
CA, USA). The reaction volume was transferred to 96-well plate and absorbance was measured at $540 \mathrm{~nm}$ in a $\mu$ Quant microplate reader (Biotek Instrument, Rochester, VT, USA). Reducing sugars levels were expressed as fold of 0 mo CG cheese.

\section{Extraction of caseins}

Caseins from CG cheese at different ripening stages were extracted as previously reported [4]. Briefly, $2.5 \mathrm{~g}$ of cheese was homogenized with $30 \mathrm{~mL}$ of acidified water with acetic acid (pH 5-6) followed by precipitation at $\mathrm{pH} 4.6$ with $25 \% \mathrm{v} / \mathrm{v}$ acetic acid solution and centrifugation (4000 rpm, $10 \mathrm{~min}$ ). The supernatant was discarded and the residue was homogenized with $20 \mathrm{~mL}$ of acidified water with acetic acid (pH 5-6) and 10 $\mathrm{mL}$ of methylene chloride, followed by centrifugation. Caseins located in the boundary phase were recovered and the process was repeated twice, washed with acetone, and were freeze dried. Extracted proteins were dissolved in Tris/2-Mercaptoethanol/ Urea buffer pH $8.6(2 \mathrm{mg} / \mathrm{mL})$. Protein content was assessed by Bradford assay (Bio-Rad, CA, USA) using casein from bovine milk as standard (0.1-0.5 mg/mL). Electrophoresis and image analysis was performed with $20 \mu \mathrm{g}$ protein diluted with Laemmli's loading buffer (Bio-Rad, Hercules, CA), boiled, loaded on a $15 \%$ sodium dodecyl sulfate-polyacrylamide gel electrophoresis (SDS-PAGE) at $100 \mathrm{~V}$ for $10 \mathrm{~min}$ and at $200 \mathrm{~V}$ for $50 \mathrm{~min}$ in a Mini-PROTEAN ${ }^{\circledR}$ Tetra Cell (Bio-Rad). After separation, gels were soaked in prefixed solution containing methanol/acetic acid/ water $50: 10: 40 \mathrm{v} / \mathrm{v} / \mathrm{v}$ for $30 \mathrm{~min}$ and stained with $0.25 \%(\mathrm{w} / \mathrm{v})$ Coomassie Brilliant Blue R250 at $55^{\circ} \mathrm{C}$ for 5 minutes. The gel was distained at the same temperature with methanol/distilled water/acetic acid 25:65:10 (v/v/v) for $45 \mathrm{~min}$ and washed three times with de ionized water [14]. Scanned images were analyzed using Image J software to calculate band intensity. A linear equation of log molecular weight versus relative migration distance for protein standards (Precision plus Protein Western $\mathrm{C}^{\mathrm{TM}}$, Bio-Rad) was used to estimate the molecular weight of proteins in samples.

\section{Protein carbonyls and AGEs-fluorophores in CG}

Extracted caseins were assessed for protein-bound carbonyls content by the 2,4-Dinitrophenylhydrazine (DNPH)- assay [15] Briefly, freeze dried extracted caseins were dissolved in Tris/2Mercaptoethanol/Urea buffer $\mathrm{pH} 8.6\left(100 \mathrm{mmol} \mathrm{L}^{-1}\right.$ Tris, $2 \mathrm{mmol}$ $\mathrm{L}^{-1}$ 2-mercaptoethanol, $8 \mathrm{mmol} \mathrm{L}^{-1}$ urea) to $10 \mathrm{mg} \mathrm{mL}^{-1}$ and reaction was carried out by mixing $250 \mu \mathrm{L}$ of this solution with $250 \mu \mathrm{L}$ of $10 \mathrm{mmol} \mathrm{L}^{-1} \mathrm{DPNH}$ solution in $2.5 \mathrm{~mol} \mathrm{~L}^{-1} \mathrm{HCl}$ for $15 \mathrm{~min}$ at room temperature in dark with constant vortexing. Protein carbonyls were precipitated with $10 \% \mathrm{w} / \mathrm{v}$ TCA on ice-bath for $30 \mathrm{~min}$ followed by centrifugation at $9000 \mathrm{~g}$ for $2 \min \left(4{ }^{\circ} \mathrm{C}\right)$. Pellets were washed three times with cold ethanol/ethyl acetate solution $(1: 1 \mathrm{v} / \mathrm{v})$ to eliminate the excess of DNPH and dissolved in $6 \mathrm{~mol} \mathrm{~L}^{-1}$ guanidine- $\mathrm{HCl}$. Absorbance was measured at $370 \mathrm{~nm}$ against a blank without DNPH. Protein-bound carbonyls were determined using extinction coefficient of DNPH $(\varepsilon=22000$ mol L-1 $\mathrm{cm}^{-1}$ ) and expressed as nmol $\mathrm{mg}^{-1}$ protein quantified by Bradford assay (Bio-Rad, Hercules, CA).

AGE-fluorophores were assessed by measuring Relative
Fluorescence Units (RFU) at $360 \mathrm{~nm}$, excitation $460 \mathrm{~nm}$ emission of freeze dried extracted caseins dissolved in Tris/2mercaptoethanol/urea buffer pH 8.6 (100 mg mL $\left.{ }^{-1}\right)$. A $\mu$ Quant microplate reader (Biotek Instrument, Rochester, VT) was used. Results were calculated as RFU \% of the 0 mo control [16].

\section{IVD of CG cheese}

CG cheese samples were successively incubated with digestive enzymes to simulate salivary, gastric, and duodenal digestion at $37^{\circ} \mathrm{C}$ and agitation (200 rpm) as previously reported [17]. Briefly, cheese samples $(10 \mathrm{~g} / 200 \mathrm{~mL})$ were homogenized with sodium maleate buffer $\left(0.05 \mathrm{~mol} \mathrm{~L}^{-1}, \mathrm{pH} 6.0\right)$; an aliquot of this homogenate was subjected to salivary digestion simulation with $3.9 \mathrm{U}$ of amylase $\mathrm{mL}^{-1}$ for $5 \mathrm{~min}$. The gastric digestion was mimicked adjusting the $\mathrm{pH}$ to 1.5 with $6 \mathrm{~mol} \mathrm{~L}^{-1} \mathrm{HCl}$ and incubating with $71.2 \mathrm{U}$ of pepsin $\mathrm{mL}^{-1}$ for $90 \mathrm{~min}$. Finally, the $\mathrm{pH}$ was adjusted to 7.5 using $6 \mathrm{~mol} \mathrm{~L}^{-1} \mathrm{NaOH}$ and sample was incubated with pancreatin $\left(9.2 \mathrm{mg} \mathrm{mL}^{-1}\right)$ and bile extract $(55.2$ $\mathrm{mg} \mathrm{mL} \mathrm{m}^{-1}$ ) for $150 \mathrm{~min}$ to simulate the duodenal digestion. IVD cheese samples were dialyzed overnight in a cellulose membrane with a cut off of $12.2 \mathrm{KDa}$ (Sigma-Aldrich, St. Louis, MO) against nanopure water at $4{ }^{\circ} \mathrm{C}$, freeze dried, stored at $-20{ }^{\circ} \mathrm{C}$ for further use.

\section{In vitro fecal fermentation of CG cheese after IVD}

Fecal samples were collected from three obese one year old diet-induced obese mice (Body Mass Index (BMI) $=5.7 \pm 0.7$ ) and from three lean mice (BMI $=3.6 \pm 0.4)$. Obese mice were under high fat (45\% kcal from fat), diet (\#D12451), containing $24 \%$ protein, $41 \%$ carbohydrate, $24 \%$ fat, plus minerals and amino acids (Research diets, Inc., New Brunswick, NJ). Lean mice were under 2018 standard diet (18\% kcal from fat), containing $18 \%$ protein, $44.2 \%$ carbohydrate, $6.2 \%$ fat, plus minerals and amino acids (Teklad Diets, Madison WI). For the fecal culture experiments, a pre-culture was prepared with fresh feces diluted with anaerobic phosphate buffer 1:10 (w/v) (1 $\left.\mathrm{mol} \mathrm{L}^{-1}, \mathrm{pH} 7.2\right)$, homogenized to produce fecal slurries from each animal donor (no pooled fecal samples), and used for inoculation of pre-culture $(10 \% \mathrm{v} / \mathrm{v})$ in a pre-reduced sterile medium at $\mathrm{pH} 7.0$ (peptone $(2$ $\left.\mathrm{g} \mathrm{L}^{-1}\right)$, yeast extract $\left(2 \mathrm{~g} \mathrm{~L}^{-1}\right), \mathrm{NaCl}\left(0.1 \mathrm{~g} \mathrm{~L}^{-1}\right), \mathrm{K}_{2} \mathrm{HPO}_{4}\left(0.04 \mathrm{~g} \mathrm{~L}^{-1}\right)$, $\mathrm{KH}_{2} \mathrm{PO}_{4}\left(0.04 \mathrm{~g} \mathrm{~L}^{-1}\right), \mathrm{NaHCO}_{3}\left(2 \mathrm{~g} \mathrm{~L}^{-1}\right), \mathrm{MgSO}_{4} \cdot 7 \mathrm{H}_{2} \mathrm{O}\left(0.01 \mathrm{~g} \mathrm{~L}^{-1}\right)$, $\mathrm{CaCl}_{2} \cdot 6 \mathrm{H}_{2} \mathrm{O}\left(0.01 \mathrm{~g} \mathrm{~L}^{-1}\right)$, Tween $80\left(2 \mathrm{~mL} \mathrm{~L}^{-1}\right)$, hemin $\left(50 \mathrm{mg} \mathrm{L}^{-1}\right)$, vitamin $\mathrm{K}\left(10 \mu \mathrm{L} \mathrm{L}^{-1}\right)$, L-cysteine $\left(0.5 \mathrm{~g} \mathrm{~L}^{-1}\right)$, bile salts $\left(0.5 \mathrm{~g} \mathrm{~L}^{-1}\right)$, resazurin ( $\left.1 \mathrm{mg} \mathrm{L}^{-1}\right)$, and distilled water) [18]. After incubation for $12 \mathrm{~h}$ at $37^{\circ} \mathrm{C}$ under agitation (200 rpm) and anaerobiosis, culture was prepared with $2.5 \%(\mathrm{v} / \mathrm{v})$ of pre-culture in culture medium containing the freeze dried CG cheese $(0,6$, or 12 mo ripening or casein, $0.2 \%, \mathrm{w} / \mathrm{v}$ ) after IVD in replacement of the yeast extract (obese control group). Feces from lean mice were cultured with casein after IVD (lean control group). After $24 \mathrm{~h}$ incubation under anaerobiosis generated by GasPak EZ ${ }^{\mathrm{TM}}$ Gas Systems (BD Diagnostic Laboratory, NJ, USA) and constant agitation, fecal bacteria and supernatants were recovered by centrifugation and stored at $-80^{\circ} \mathrm{C}$ for further analysis.

\section{Analysis of relative abundances of DNA fecal bacterial}

DNA relative abundances of fecal bacteria were analyzed by PCR. Briefly, DNA was extracted from pellets recovered after 
fecal fermentation using QIAamp DNA Stool Mini Kit (QIAGEN Inc, CA, USA) according to the manufacturer's protocol. The concentrations of DNA and absorbance ratio 260/280 $\mathrm{nm}$ as measurement of purity were assessed using a NanoDrop 2000 spectrophotometer (Thermo Scientific, NC, USA). PCR reaction mixtures (total of $10 \mu \mathrm{L}$ ) contained $5 \mu \mathrm{L}$ of Sso Advanced ${ }^{\mathrm{TM}}$ SYBR $®$ Green Supermix (Bio-Rad, CA, USA), $0.4 \mu \mathrm{L}$ of primer mix (forward and reverse, final concentration $200 \mathrm{nM}$ ), $2 \mu \mathrm{L}$ of adjusted ( $2{\left.\mathrm{ng} \mu \mathrm{L}^{-1}\right)}$ template DNA or non-template control, and $2.6 \mu \mathrm{L}$ nuclease-free water (Qiagen $\mathrm{GmbH}$, Hilden, Germany). PCR conditions were as follows: $95^{\circ} \mathrm{C}$ for $30 \mathrm{~s}$ and 40 cycles at $95^{\circ} \mathrm{C}$ for $5 \mathrm{~s}$ and $55^{\circ} \mathrm{C}$ for $30 \mathrm{~s}$. A melt curve analysis was performed to verify the specificity of the primers using the following conditions: 65 to $95{ }^{\circ} \mathrm{C}$ at $0.5{ }^{\circ} \mathrm{C}$ increments. Relative bacterial population was quantified by the Livak Method $\left(2-\frac{\Delta \Delta C}{T}\right)$ using as reference the universal primer CT values. Data was normalized to cultures fermented with casein as substrate. Primer sequences obtained from [19] are presented in Table 1.

\section{Short-chain fatty acids (SCFAs)}

Propionic, butyric, and acetic acids were quantified in supernatants from fecal fermentation as previously reported [20]. Briefly, supernatants filtered through a $0.22 \mu \mathrm{m}$ PVDF filter (Thermo Scientific, TN, USA) were analyzed by High Performance Liquid Chromatography (HPLC) using the Aminex HPX-87H strong cation-exchange resin column (300 x $7.8 \mathrm{~mm}$ i.d.) and ion exclusion microguard refill cartridge (Bio-Rad, CA, USA) in a Waters 600S Separation Module equipped with an auto injector 717 Plus, a photodiode array detector (999 PAD) (Waters, MA, USA) and the Millennium software was used for HPLC analysis. A sample of $20 \mu \mathrm{L}$ was eluted with $\mathrm{H}_{2} \mathrm{SO}_{4}\left(0.016 \mathrm{~mol} \mathrm{~L}^{-1}\right)$ at 0.6 $\mathrm{mL} \mathrm{min}^{-1}$ and $35{ }^{\circ} \mathrm{C}$. SCFAs were identified and quantified by comparing retention times, UV-visible spectral data, and peak areas to known standards.

\section{Cell culture}

The human colon fibroblast CCD-18Co cells were purchased from ATCC (Manassas, VA). Cells were cultured using high glucose Dulbecco's Modified Eagle Medium, supplemented with $1 \%$ penicillin/streptomycin solution, $1 \%$ non-essential amino acids $(10 \mathrm{mM}), 1 \%$ sodium pyruvate $(100 \mathrm{mM})$ and $20 \%$ of FBS (Invitrogen, Carlsbad, CA). Cells were maintained at $37{ }^{\circ} \mathrm{C}$ with a humidified 5\% CO2 atmosphere.

\section{Cell Proliferation}

Cells were seeded ( $2 \times 10^{4}$ onto a 24 -well plate $)$ and incubated overnight to allow cell attachment. Cell number was determined using an electronic cell counter ( $\mathrm{Z}^{\mathrm{TM}}$ Series, Beckman Coulter, Inc) after $48 \mathrm{~h}$ incubation in culture media supplemented with sterile filtered supernatant $(2.5-10 \%, \mathrm{v} / \mathrm{v})$ from fecal fermentation. Results were expressed as \% of controls incubated with culture media supplemented with sterile culture medium used for fecal fermentation.

\section{Generation of Reactive Oxygen Species (ROS)}

Metabolites produced during fecal fermentation of CG cheese $(0,6$, or 12 mo ripening) after IVD as detailed in section 2.7 were assessed for their effects in protecting human fibroblast CCD-18Co colon cells from production of ROS when challenged with E. coli lipopolysaccharides (LPS) mimicking obesityinduced inflammation. ROS levels were quantified using the dichlorofluorescein diacetate (DCFH-DA) fluorescent probe as previously reported [21]. Briefly, cells seeded (15 x $10^{3}$ cells/ well) in a 96-well plate were incubated overnight to allow cell attachment followed by incubation with culture media supplemented with composite of sterile filtered fecal culture supernatants $(2.5 \% \mathrm{v} / \mathrm{v})$ for $1 \mathrm{~h}$. ROS generation was induced with LPS $(2 \mu \mathrm{g} / \mathrm{mL})$ for 2 hours. ROS levels are proportional to Relative Fluorescent Units (RFU) detected with DCFH-DA $(10 \mu \mathrm{M})$ after $30 \mathrm{~min}$ reaction and monitored at $520 \mathrm{~nm}$ emission and $480 \mathrm{~nm}$ excitation with a $\mu$ Quant micro plate reader (Biotek Instrument, Rochester, VT, USA). Fecal culture supernatants of feces fermented with casein after IVD were used as control. Values were normalized to RFU of controls treated with casein fecal culture supernatants no challenged with LPS.

\section{Statistical analysis}

Quantitative data represent mean values with the respective standard deviation (SD) or standard error of the mean (SE) of three or more replicates. One-way analysis of variance (ANOVA)

Table 1: Sequences of primers used for PCR analysis of DNA

\begin{tabular}{|c|c|c|c|c|}
\hline Phylum & Class/Family/Genus & Species/Group & Primer sequence $\left(5^{\prime}-3^{\prime}\right)$ & $\begin{array}{l}\text { Approximately } \\
\text { amplicon size (bp) }\end{array}$ \\
\hline Universal & All & All & $\begin{array}{l}\text { ACTCCTACGGGAGGCAGCAGT } \\
\text { GTATTACCGCGGCTGCTGGCAC }\end{array}$ & $174-179$ \\
\hline Bacteroidetes & All & All & $\begin{array}{l}\text { GGARCATGTGGTTTAATTCGATGAT } \\
\text { AGCTGACGACAACCATGCAG }\end{array}$ & 126 \\
\hline Actinobacteria & Bifidobacterium & spp. & $\begin{array}{l}\text { GCGTGCTTAACACATGCAAGTC } \\
\text { CACCCGTTTCCAGGAGCTATT }\end{array}$ & 126 \\
\hline Firmicutes & All & All & $\begin{array}{l}\text { TGAAACTYAAAGGAATTGACG } \\
\text { ACCATGCACCACCTGTC }\end{array}$ & 157 \\
\hline Proteobacteria & Enterobacteriaceae & group & $\begin{array}{c}\text { CATTGACGTTACCCGCAGAAGAAGC } \\
\text { CTCTACGAGACTCAAGCTTGC }\end{array}$ & 195 \\
\hline Firmicutes & Enterococcus & spp. & $\begin{array}{c}\text { CССTTATTGTTAGTTGCCATCATT } \\
\text { ACTCGTTGTACTTCCCATTGT }\end{array}$ & 144 \\
\hline
\end{tabular}


followed by a Bonferroni post-hoc test were performed with Graph Pad Prism (San Diego, CA). A value of P $<0.05$ was considered statistically significant. Principal Component Analysis (PCA) was performed using SPSS version 15.0 (SPSS Inc., Chicago, IL). Figures were created with Graph Pad Prism and Sigma Plot ${ }^{\mathrm{TM}}$ (San Jose, CA).

\section{Results}

\section{Viability of L. helveticus and reducing sugars during ripening}

Results showed the viability of L. helveticus decreased to levels $<30$ cfu g$^{-1}$ numbers within 12 mo of ripening (Fig 1a). The content of reducing sugars increased during the first 6 mo to 2 -fold of 0 mo and decreased within 6 to 24 mo down to levels found in the 0 mo control (Fig. 1b).

\section{Effects of ripening on CG caseins}

CG caseins analyzed by electrophoresis showed that bands of higher molecular size tend to decrease throughout the ripening as illustrated in Fig. 2a. The band intensities of P1 and P2, 25.0-29.4 $\mathrm{kDa}$, decreased significantly at 6 and 12 mo ripening compared to 0 mo (Fig. 2b). The bands of intermediate molecular size P3 and P4 (22-23.1 kDa) increased at 6 mo ripening as a result of proteolysis of larger molecular size proteins and decreased to 0 mo levels at 12 mo ripening and beyond. The proteins of lower molecular size (17.9-19.4 kDa) did not change throughout ripening up to $18 \mathrm{mo}$ but decreased significantly at 24 mo ripening.

\section{Effects of ripening on protein carbonyls and AGEs contents in CG cheese}

Results showed that content of protein carbonyl products increased significantly with ripening (up to 2.7 -fold of 0 mo control at 12 mo, Fig. 2c); this was accompanied by an increase in the production of AGEs-fluorophores that reached maximum concentrations at 12 mo ripening (1.7-fold of 0 mo control, Fig. 2d).

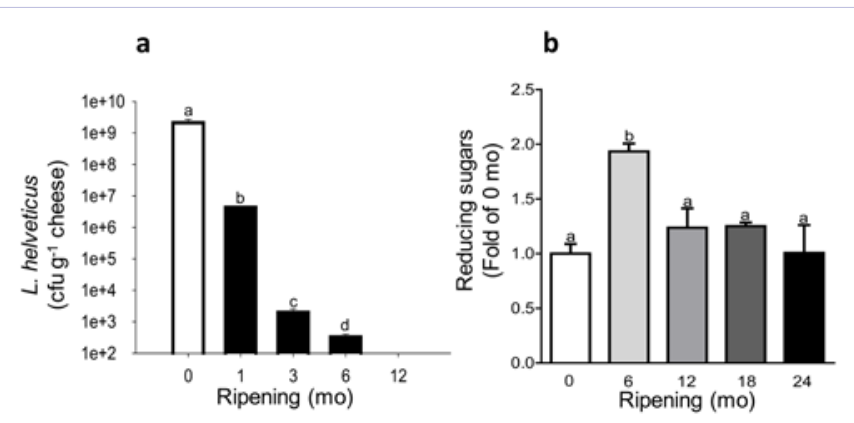

Figure 1: L. helveticus viability and reducing sugars levels during CG cheese ripening. (a) L. helveticus viability. L. helveticus were counted in selective agar and colony forming units (cfu) $\mathrm{g}^{-1}$ of cheese were determined after $48 \mathrm{~h}$ incubation at $37{ }^{\circ} \mathrm{C}$ as detailed in materials and methods. (b) Reducing sugars levels. Reducing sugars were quantified by the 3,5-dinitrosalicylic acid (DNS) assay as detailed in materials and methods. A composite from three cheese samples was analyzed in triplicate. Values are average $\pm S D,(n=3)$, different letters indicate statistical difference at $\mathrm{p}<0.05$

\section{Modulation of fecal bacteria and production of SCFAs by CG cheese after IVD}

Results showed that CG cheese after IVD did not change relative proportions of Firmicutes in feces from obese mice (ranged from 0.96-fold to 1.1-fold of obese control) (data not shown); however, the Bacteroidetes/Firmicutes ratio tended to increase in feces when fermented with 0 and 6 mo CG cheese after IVD (Fig. 3a).

Enterococcus, a genus of lactic acid bacteria and common commensal organisms in the intestines, were significantly less abundant in feces from lean controls compared to the obese controls. The levels of Enterococcus in obese feces fermented with 0 mo CG cheese were similar to obese control fermented with casein after IVD. However Enterococcus DNA levels were significantly lower after fermentation with 6 and 12 mo ripened CG cheese after IVD and similar to the levels found in lean controls (Fig. 3b). In addition, the DNA levels of Enterobacteriaceae were lower in feces from lean controls and the fecal fermentation with cheese (6-12 mo ripening) also decreased their relative abundance to levels similar to lean controls (Fig. 3c). The relative abundance of Bifidobacterium spp, even though did not reach significance, tended to increase in feces cultured with aged cheese (Fig. 3d). The lack of statistical significance among experimental groups on DNA relative abundances of the bacteria assessed by PCR was partially due to the high variability of fecal samples obtained from three different mice donors.

However, the PCA analysis showed that obese and 0 mo are located close while the 6 and 12 mo shift closer to the lean group indicating that bacteria abundances are similar to the lean group (Fig. 3e).

The production of SCFAs has been associated with the growth of probiotic bacteria and seems to play an important role for epithelial proliferation in the gut [22]. Results showed that SCFAs concentrations in supernatants from fecal fermentation of CG after IVD were similar among ripening periods (0-12 mo) and ranged from $313 \pm 17$ to $324 \pm 21 \mu \mathrm{mol} \mathrm{L}^{-1}$ for butyric acid, and $70 \pm 5$ to $75 \pm 6 \mu \mathrm{mol} \mathrm{L}^{-1}$ for acetic acid with non-detectable levels of propionic acid.

\section{Metabolites produced by fecal fermentation of CG after IVD protected colon cells against oxidative stress}

Protection of colon fibroblastCCD-18Co cells against oxidative stress was assessed with fecal culture supernatant at doses that cell proliferation was not inhibited $2.5 \%$ (v/v) (data not shown).

ROS are key signaling molecules which play an essential role in the progression of inflammatory disorders. Results showed that LPS challenge increased ROS levels in CCD-18Co cells up to 1.4-fold of cells pre-treated with supernatants from obese fecal fermentation of casein after IVD and not challenged with LPS. Pretreatment with 6 and 12 mo CG obese fecal culture supernatants prevented the ROS production and maintained levels down to 1.1- and 0.9-fold of control cells pre-treated with casein obese fecal supernatants and not challenged with LPS (Fig. 4a). 

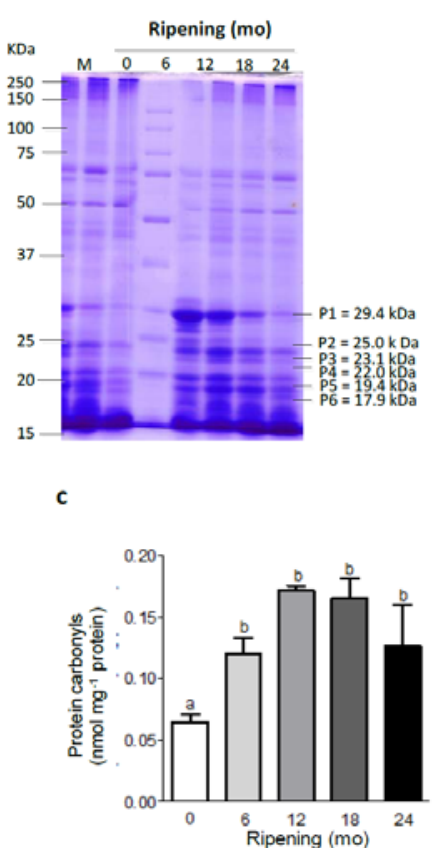

b
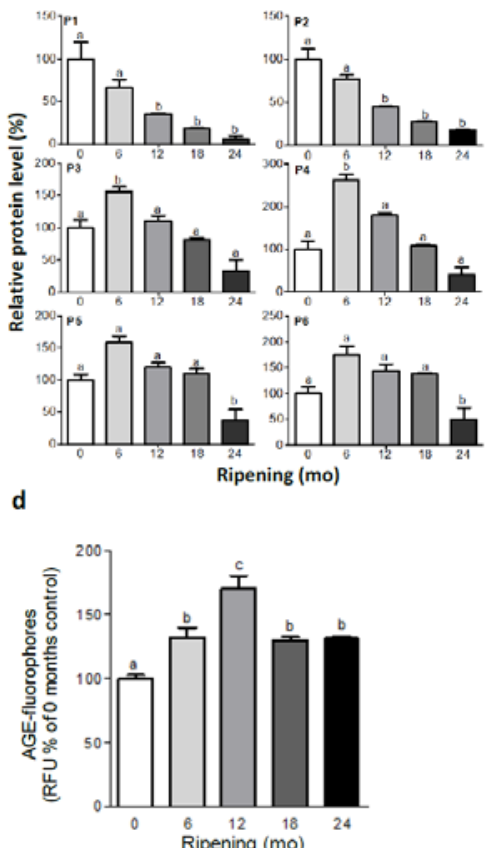

Figure 2: Cheese ripening involves casein proteolysis and the generation of protein carbonyls and AGEs. (a) SDS-PAGE and (b) Band intensities of CG cheese caseins. Proteins were extracted from a composite of three cheeses. To illustrate differences on protein concentrations, the relative intensity of bands P1 to P6 were determined using the Image J software as outlined in materials and methods. (c) Protein carbonyls and (d) AGEfluorophores. Protein carbonyls were analyzed by the 2,4-dinitrophenylhydrazine (DNPH)-assay. AGE-fluorophores levels were determined based on the relative fluorescence units (RFU) at $360 \mathrm{~nm}$ excitation and $460 \mathrm{~nm}$ emission, as outlined in materials and methods. Values are average \pm SD, $(n=3)$, different letters indicate statistical difference at $\mathrm{p}<0.05$
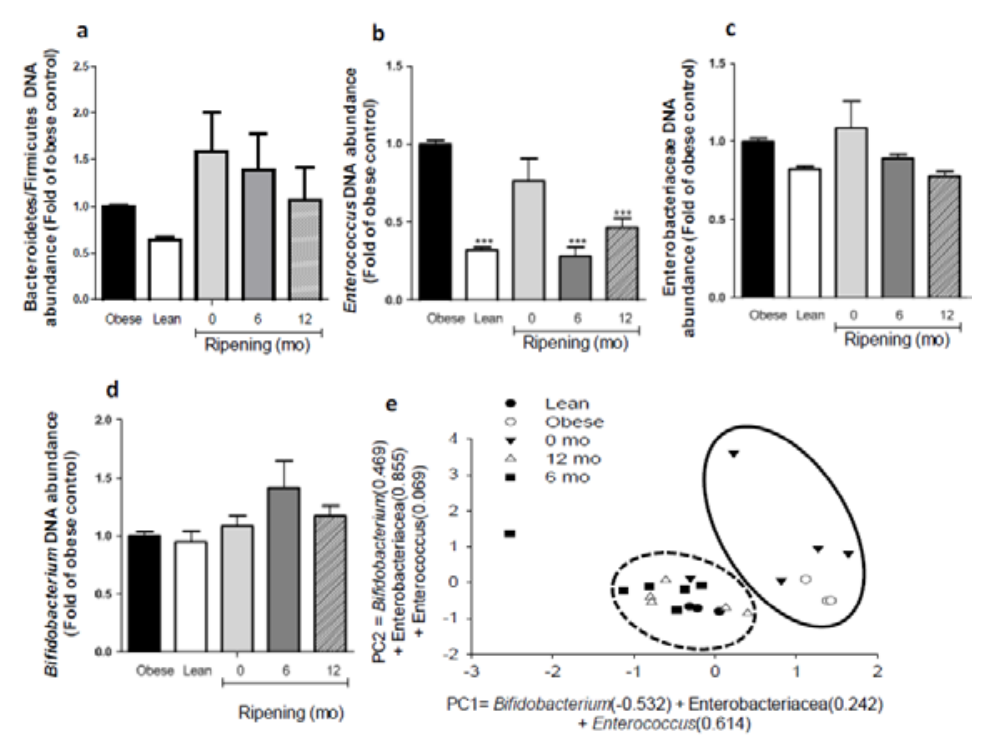

Figure 3: CG cheese proteins after IVD change relative abundances of bacteria in feces from obese mice. (a) Bacteriodetes/Firmicutes DNA abundance ratio, (b) Enterococcus, (c) Enterobacteriaceae, (d) Bifidobacterium sp, and (e) PCA of relative DNA levels of the analyzed bacteria. Circles in PCA represent experimental units that are alike in DNA levels of bacteria. Obese control and 0 mo are enclosed by continuous line circle, lean, 6 and $12 \mathrm{mo}$ are enclosed by dashed line circle. In vitro fecal fermentation was prepared using fecal slurries from obese mice ( $\mathrm{n}=3$, no pooled fecal samples) in prereduced modified medium containing CG cheese $(0,6$, and $12 \mathrm{mo}$ ) or casein (obese and lean controls) after IVD for $24 \mathrm{~h}$ under anaerobiosis and constant agitation as outlined in materials and methods. DNA was extracted from fecal material and analyzed for relative abundances of bacterial populations by PCR as detailed in materials and methods. Values are average $\pm \mathrm{SE},{ }^{* * *}, \mathrm{p}<0.01$ compared to the obese control. 


\section{Discussion}

Counts of L. helveticus were reduced within 6 mo ripening. These results are in agreement with bacteria counts in Swiss-type cheeses produced with $\mathrm{L}$. helveticus during ripening processes [23]. Literature reports that survival of SLAB is reduced during cheese ripening due to the decrease of lactose availability and autolytic activities [24]. The substrate changes that cause autolysis and release of bacterial enzymes during cheese ripening are associated with the cheese making process involving heat, acidic, osmotic, oxidative stresses on microorganisms and changes in the $\mathrm{pH}$, water activity (aw), and redox potential gradients in the matrix $[24,25]$. However, NSLAB might be viable and become the dominant microflora in the ripened cheese due to resistance to environmental stresses [24, 25].

The increase of reducing sugars during the first 6 mo was likely related to the conversion of lactose to glucose and galactose or galactose- 6 phosphate by starter and NSLAB, which can occur at a higher rate than their use as source of energy, and as a result of the activity of enzymes, released by autolysis of bacteria cultures. Reducing sugars decreased after 6 mo ripening, which suggests their reaction with proteins to produce the protein carbonyls and other precursors of MRPs as demonstrated in "Formation of early and advanced Maillard reaction products correlates to the ripening of cheese" [4]. In addition, reducing sugars can be used as a source of energy by NSLAB during ripening, that were shown to survive the environmental changes occurring during cheese ripening [25]

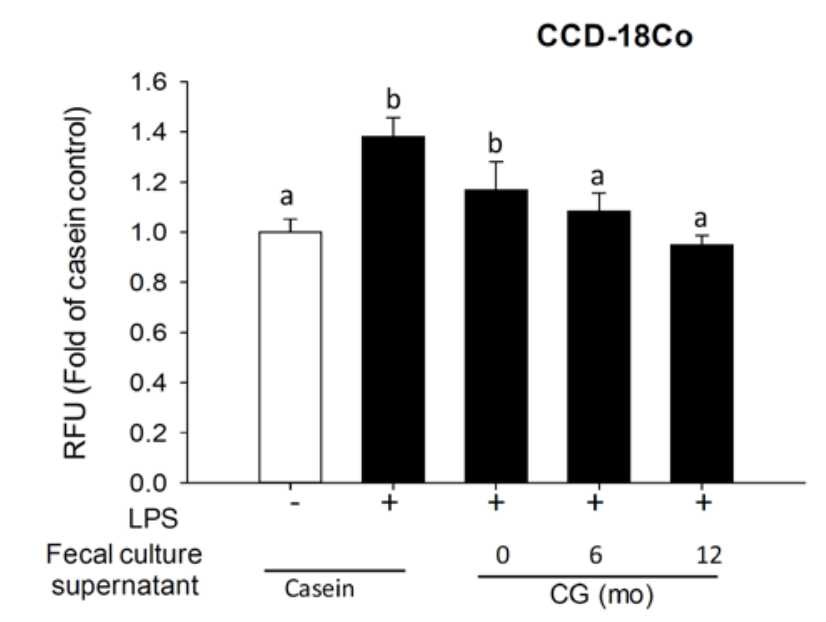

Figure 4: Effects of metabolites produced by obese fecal bacteria fermentation of GC cheese after IVD on reactive oxygen species (ROS) levels in human colon CCD-18Co fibroblast cells. Relative fluorescent units (RFU) were determined in cells pre-treated with sterile filtered fecal culture supernatants $(2.5 \% \mathrm{v} / \mathrm{v})$ for $1 \mathrm{~h}$ and challenged with LPS $(2 \mu \mathrm{g} /$ $\mathrm{mL}$ ) for 2 hours by DCFH-DA assay as detailed in materials and methods. Fecal culture supernatants of feces fermented with casein after IVD were used as control. Values were normalized to RFU of controls treated with fecal culture supernatants of casein after IVD no challenged with LPS. Values are average $\pm S D,(n \geq 6)$, different letters indicate statistical difference at $\mathrm{p}<0.05$.
Changes in CG caseins of higher molecular size (P1-P2) are associated with the composition of starter cultures and proteolysis occurring during the ripening period [26]. In addition, the residual activities of coagulants (chymosin, pepsin, or fungal acid proteinase) or at less extent, milk enzymes (plasmin and perhaps cathepsin D), produce large and intermediate-sized peptides. Specially, enzymes released due to autolysis of starter cultures and the adjunct L. helveticus are highly proteolytic and have shown to play a critical role in texture and flavor formation in cheese as well as the synthesis of bioactive peptides in situ $[1,23]$. During ripening, CG caseins of lower molecular size (P3-P6) indicates that cheese ripening is a continuous dynamic process in which proteolysis of larger molecular size proteins counterbalances the continuous degradation of lower molecular size proteins. These changes in cheese caseins are associated with proteolytic activity of SLAB and NSLAB that contribute to the breakdown of proteins to produce low molecular size caseins, small peptides and free amino acids [23]. In general, significant changes in the protein band intensities occurred within 6-12 mo ripening, implying that an extended ripening beyond 12 mo might not be necessary to develop flavor and texture; when a highly proteolytic strain such as L. helveticus is used as adjunct culture.

Protein carbonyls are formed only in the presence of reducing sugars and may act as early precursors for the later production of AGEs- fluorophores [16]. These compounds have been used as a parameter of ripening in cheeses $[4,27,28]$ and their formation was accompanied by the loss of galactose in Manchego cheese [29].

Also, results showed that CG after $24 \mathrm{~h}$ cheese production and day 0 of ripening had a $\mathrm{pH}=4.9$ and remained almost constant throughout ripening ( 0 to $24 \mathrm{mo})(\mathrm{pH}=5.08 \pm 0.06$ ) (data not shown). Lactose conversion to lactic acid occurs during the first $24 \mathrm{~h}$ of cheese production, coupled with growth of SLAB, lactic acid fermentation, and decrease in $\mathrm{pH}$ to approximately 5.1 to $5.25[24]$.

Furthermore, glycated proteins were shown to be less susceptible to pepsin hydrolysis when compared to nonglycated ones and to potentially exert a beneficial effect in the lower gastrointestinal tract by modulating gut microbiota [8, 9]. Likewise, sodium caseinate glycated via Maillard reaction with galactose and lactose and corresponding peptides (which might resemble reactions occurring in cheese) were quickly fermented after simulated gastrointestinal digestion by strains of Lactobacillus, Streptococcus and Bifidobacterium. The bacteria growth was promoted at a greater extent than $\beta$ - lactoglobulin complexes or even glucose [30]. This study suggested that conjugation of milk proteins with galactose and lactose via the Maillard reaction could be an efficient method to obtain novel food ingredients with a potential prebiotic character. These reactions occur during cheese ripening [4] and contribute to the bioactive potential of ripened cheese. This has been supported by an in vitro study demonstrating that MRPs from sodium caseinate lactose and glucose, exerted higher antioxidant activity than the intact milk protein and protected against 
oxidative damage [31].Furthermore, the same research group demonstrated later in vivo that MRPs from sodium caseinate and their correspondent products after fermentation by Lactobacillus enhanced cardiovascular health in mouse and rat models [32]. The antioxidant activity and cardiovascular protective potential of MRPs derived from milk proteins increased after enzymatic hydrolysis [33] and after fermentation with Lactobacillus strains [34]. However, the bifidogenic activity of MRPs has been questioned since caseinomacropeptide nonenzymatically glycosylated with prebiotic carbohydrates exerted a similar bifidogenic activity to that of the corresponding prebiotic carbohydrates in cultured human feces after being subjected to in vitro gastrointestinal digestion [35].

Gut microbiota composition can be altered by diet and influence the host health. Alterations in the gut microbiota of obese mice and humans have been associated with increase of Firmicutes and decrease of Bacteroidetes; the two dominant bacteria phylum in the human gut. A previous study reported that Bacteroidetes/Firmicutes ratio is low in obese state and this ratio increased with weight loss [36]. These alterations contribute to the increased efficiency of energy harvest in obesity [37]. Even though only an increasing trend in relative DNA abundances of Bacteroidetes to Firmicutes was found; the changes in Enterococcus DNA relative abundances were consistent with a previous study reporting that Enterococcus population is reduced in feces from lean rats compared to feces from obese rats [38]. Enterococcus abundance was positively correlated with genes and metabolites promoted by high protein diets and generally observed to be involved in colonic disease [39]. However, some Enterococcus species such as Enterococcus faecalis FK-23 exhibit anti-obesity effects in mice fed high fat diet [40]. Further in vivo research is needed to elucidate the specific Enterococcus species that seem to be inhibited by consumption of ripened cheese.

Likewise, a promising trend indicating decreasing levels of Enterobacteriaceae in obese feces fermented with cheese after IVD are supported by a previous study reporting that significantly higher levels of Enterobacteriaceae are present in feces of obese/ overweight children [41]. Similarly, a promising trend to increase the levels of Bifidobacterium will need to be further investigated in vivo due to its known role as probiotic beneficial bacteria and its negative association with BMI in a study of feces from obese and lean subjects [42].

In general, only trends were observed among experimental groups regarding relative abundances of these bacteria assessed by PCR $(p>0.05)$ due to the high variability of fecal samples obtained from three different mice donors. Similar results have been previously reported [35]. Similarly, concentrations of SCFAs in fecal culture supernatant were not statistically different from the obese controls, though they have the tendency to increase in cultures with 6 and 12 mo ripening. The main effects of glycosylated caseino macro peptides seems to be their bifidogenic activity, no the production of SCFAs as is reported for dietary fiber [43].

The microbial metabolites in supernatants from obese feces cultured with 6 and 12 mo CG after IVD seemed to protect the fibroblast CCD-18Co cells from LPS-induced ROS at similar extent and maintained ROS levels down to the levels of controls not challenged with LPS. These results are supported by a previous study demonstrating that longer ripened dairy products impact positively levels of oxidative stress [44]. Furthermore, recent evidence indicates benefits of intestinal bacteria and metabolic activities, partly due to controlled release of ROS. Thus, gastrointestinal bacteria has been considered as an active adjuvant treatment for mood disorders [45].

In conclusion, our results demonstrated that proteins and peptides produced during the ripening process in CG cheddar cheese and those released after in vitro gastric digestion, can act as modulators of bacterial growth in feces. There was a promising trend to shift relative abundances of specific genera and phyla of obese mice towards a profile that resemble the lean mice fecal bacteria proportions. In addition, metabolites produced by fecal bacteria fermentation of CG cheese after IVD might protect colon fibroblast cells from chronic inflammation induced by ROS. However, further in vivo studies are needed to validate the potential of ripened cheese consumption for manipulation of gut microbial communities in obesity.

\section{Acknowledgement}

The authors are grateful for the financial support of the Build Dairy Program, managed by the Western Dairy Center at Utah State University. The authors would to thank Paulina Pilla, student from Pan-American School of Agriculture, Zamorano, Honduras for her technical assistance and the WSU creamery personnel for kindly providing the CG cheese samples kept in inventory up to 24 mo for our study.

\section{References}

1. Slattery L, O'Callaghan J, Fitzgerald GF, Beresford T, Ross RP. Invited review: Lactobacillus helveticus--a thermophilic dairy starter related to gut bacteria. Journal of dairy science. 2010;93(10):4435-4454. doi: $10.3168 /$ jds.2010-3327

2. Hickey DK, Kilcawley KN, Beresford TP, Sheehan EM, Wilkinson MG. Starter strain related effects on the biochemical and sensory properties of Cheddar cheese. The Journal of dairy research. 2007;74(1):9-17.

3. Higurashi S, Kunieda Y, Matsuyama H, Kawakami H. Effect of cheese consumption on the accumulation of abdominal adipose and decrease in serum adiponectin levels in rats fed a calorie dense diet. Int Dairy J. 2007;17(10):1224-1231.

4. Spanneberg R, Salzwedel G, Glomb MA. Formation of early and advanced Maillard reaction products correlates to the ripening of cheese. Journal of agricultural and food chemistry. 2012;60(2):600607. doi: 10.1021/jf204079f

5. Somoza V. Five years of research on health risks and benefits of Maillard reaction products: an update. Molecular nutrition \& food research. 2005;49(7):663-672.

6. Sebekova K, Krajcoviova-Kudlackova M, Schinzel R, Faist V, Klvanova J, Heidland A. Plasma levels of advanced glycation end products in healthy, long-term vegetarians and subjects on a western mixed diet. European journal of nutrition. 2001;40(6):275-281.

7. Morales FJ, Somoza V, Fogliano V. Physiological relevance of dietary melanoidins. Amino acids. 2012;42(4):1097-1109. doi: 10.1007/ s00726-010-0774-1

8. Swiatecka D, Narbad A, Ridgway KP, Kostyra H. The study on the impact 
of glycated pea proteins on human intestinal bacteria. International journal of food microbiology. 2011;145(1):267-272. doi: 10.1016/j. ijfoodmicro.2011.01.002.

9. Świątecka D, Małgorzata I, Aleksander Ś, Henryk K, Elżbieta K. The impact of glycated pea proteins on bacterial adhesion. Food Research International. 2010;43(6):1566-1576.

10. Lin H, Boylston TD, Luedecke LO, Shultz TD. Conjugated linoleic acid content of cheddar-type cheeses as affected by processing. J Food Sci. 1999;64(5):874-878.

11. Karimi R, Mortazavian AM, Amiri-Rigi A. Selective enumeration of probiotic microorganisms in cheese. Food microbiology 2012;29(1):1-9.

12. Fukuda K, Yamamoto A, Ganzorig K, Khuukhenbaatar J, Senda A, Saito $\mathrm{T}$, et al. Chemical characterization of the oligosaccharides in Bactrian camel (Camelus bactrianus) milk and colostrum. Journal of dairy science. 2010;93(12):5572-5587. doi: 10.3168/jds.2010-3151

13. King BC, Donnelly MK, Bergstrom GC, Walker LP, Gibson DM. An optimized microplate assay system for quantitative evaluation of plant cell wall-degrading enzyme activity of fungal culture extracts. Biotechnology and Bioengineering. 2009;102(4):1033-1044. doi: 10.1002/bit.22151

14. Kurien BT, Scofield RH. Accelerated Coomassie Blue staining and destaining of SDS-PAGE gels with application of heat. Methods Mol Biol. 2012;869:471-479. doi: 10.1007/978-1-61779-821-4_41

15. Hawkins CL, Morgan PE, Davies MJ. Quantification of protein modification by oxidants. Free radical biology \& medicine. 2009;46(8):965-988. doi: 10.1016/j.freeradbiomed.2009.01.007

16. Liggins J, Furth AJ. Role of protein-bound carbonyl groups in the formation of advanced glycation endproducts. Biochim Biophys Acta 1997; 1361(2):123-130.

17. Hollebeeck S, Borlon F, Schneider Y-J, Larondelle Y, Rogez H. Development of a standardised human in vitro digestion protocol based on macronutrient digestion using response surface methodology. Food Chemistry. 2013;138(2-3):1936-1944. doi 10.1016/j.foodchem.2012.11.041

18. Sanchez-Patan F, Cueva C, Monagas M, Walton GE, Gibson GR, Quintanilla-Lopez JE, et al. In vitro fermentation of a red wine extract by human gut microbiota: changes in microbial groups and formation of phenolic metabolites. Journal of agricultural and food chemistry 2012;60(9):2136-2147. doi: 10.1021/jf2040115

19. Bergstrom A, Licht TR, Wilcks A, Andersen JB, Schmidt LR, Gronlund $\mathrm{HA}$, et al. Introducing GUt low-density array (GULDA): a validated approach for qPCR-based intestinal microbial community analysis FEMS Microbiol Lett. 2012;337(1):38-47. doi: 10.1111/15746968.12004

20. Campos D, Betalleluz-Pallardel I, Chirinos R, Aguilar-Galvez A Noratto G, Pedreschi R. Prebiotic effects of yacon (Smallanthus sonchifolius Poepp. \&amp; Endl), a source of fructooligosaccharides and phenolic compounds with antioxidant activity. Food Chemistry 2012;135(3):1592-1599. doi: 10.1016/j.foodchem.2012.05.088.

21. Noratto GD, Kim Y, Talcott ST, Mertens-Talcott SU. Flavonol-rich fractions of yaupon holly leaves (Ilex vomitoria, Aquifoliaceae) induce microRNA-146a and have anti-inflammatory and chemopreventive effects in intestinal myofibroblast CCD-18Co cells. Fitoterapia. 2011;82(4):557-569. doi: 10.1016/j.fitote.2011.01.013.

22. Delzenne NM, Neyrinck AM, Cani PD. Modulation of the gut microbiota by nutrients with prebiotic properties: consequences for host health in the context of obesity and metabolic syndrome. Microbial cell factories. 2011;10 Suppl 1:S10. doi: 10.1186/1475-2859-10-S1-S10

23. Sadat-Mekmene L, Richoux R, Aubert-Frogerais L, Madec MN, Corre C, Piot M, et al. Lactobacillus helveticus as a tool to change proteolysis and functionality in Swiss-type cheeses. Journal of dairy science. 2013;96(3):1455-1470. doi: 10.3168/jds.2012-6179

24. Beresford TP, Fitzsimons NA, Brennan NL, Cogan TM. Recent advances in cheese microbiology. Int Dairy J. 2001;11(4-7):259-274.

25. Gatti M, Bottari B, Lazzi C, Neviani E, Mucchetti G. Invited review: Microbial evolution in raw-milk, long-ripened cheeses produced using undefined natural whey starters. Journal of dairy science. 2014;97(2):573-591. doi: 10.3168/jds.2013-7187.

26. Sforza S, Cavatorta V, Lambertini F, Galaverna G, Dossena A, Marchelli R. Cheese peptidomics: a detailed study on the evolution of the oligopeptide fraction in Parmigiano-Reggiano cheese from curd to 24 months of aging. Journal of dairy science. 2012;95:3514-3526. doi: 10.3168/jds.2011-5046

27. Kokawa M, Ikegami S, Chiba A, Koishihara H, Trivittayasil V, Tsuta M, et al. Measuring Cheese Maturation with the Fluorescence Fingerprint. Food Science and Technology Research. 2015;21(4):549-555.

28. Schwietzke U, Malinowski J, Zerge K, Henle T. Quantification of Amadori products in cheese. European Food Research and Technology. 2011;233(2):243-251. doi:10.1007/s00217-011-1509-6

29. Corzo N, Villamiel M, Arias M, Jimenez-Perez S, Morales FJ. The Maillard reaction during the ripening of Manchego cheese. Food Chemistry. 2000;71(2):255-258.

30. Corzo-Martinez M, Avila M, Moreno FJ, Requena T, Villamiel M. Effect of milk protein glycation and gastrointestinal digestion on the growth of bifidobacteria and lactic acid bacteria. International journal of food microbiology. 2012;153(3):420-427. doi: 10.1016/j. ijfoodmicro.2011.12.006

31. Oh NS, Young Lee J, Lee HA, Joung JY, Shin YK, Kim SH, et al. Chemical characteristics and enhanced hepatoprotective activities of Maillard reaction products derived from milk protein-sugar system. Journal of dairy science. 2016;99(2):947-958. doi: 10.3168/jds.2015-10009

32. Oh NS, Park MR, Lee KW, Kim SH, Kim Y. Dietary Maillard reaction products and their fermented products reduce cardiovascular risk in an animal model. Journal of dairy science. 2015;98(8):5102-5112. doi: $10.3168 /$ jds.2015-9308

33. Oh NS, Lee HA, Lee JY, Joung JY, Lee KB, Kim Y, et al. The dual effects of Maillard reaction and enzymatic hydrolysis on the antioxidant activity of milk proteins. Journal of dairy science. 2013;96(8):4899-4911. doi: 10.3168/jds.2013-6613.

34. Oh NS, Kwon HS, Lee HA, Joung JY, Lee JY, Lee KB, et al. Preventive effect of fermented Maillard reaction products from milk proteins in cardiovascular health. Journal of dairy science. 2014;97(6):33003313. doi: $10.3168 /$ jds.2013-7728

35. Hernandez-Hernandez O, Sanz ML, Kolida S, Rastall RA, Moreno FJ. In vitro fermentation by human gut bacteria of proteolytically digested caseinomacropeptide nonenzymatically glycosylated with prebiotic carbohydrates. Journal of agricultural and food chemistry. 2011;59(22):11949-11955. doi: 10.1021/jf203576g

36. Turnbaugh PJ, Backhed F, Fulton L, Gordon JI. Diet-induced obesity is linked to marked but reversible alterations in the mouse distal gut microbiome. Cell host \& microbe. 2008;3(4):213-223. doi: 10.1016/j. chom.2008.02.015 
37. Murphy EF, Cotter PD, Healy S, Marques TM, O'Sullivan O, Fouhy $\mathrm{F}$, et al. Composition and energy harvesting capacity of the gut microbiota: relationship to diet, obesity and time in mouse models. Gut. 2010;59(12):1635-1642. doi: 10.1136/gut.2010.215665

38. Sefcikova Z, Kmet V, Bujnakova D, Racek L, Mozes S. Development of gut microflora in obese and lean rats. Folia Microbiol. 2010;55(4):373375. doi: $10.1007 / \mathrm{s} 12223-010-0061-2$

39. Mu C, Yang Y, Luo Z, Guan L, Zhu W. The Colonic Microbiome and Epithelial Transcriptome Are Altered in Rats Fed a High-Protein Diet Compared with a Normal-Protein Diet. The Journal of nutrition. 2016;146(3):474-483. doi: 10.3945/jn.115.223990

40. Kondoh M, Shimada T, Fukada K, Morita M, Katada K, Higashimura Y, et al. Beneficial effects of heat-treated Enterococcus faecalis FK-23 on high-fat diet-induced hepatic steatosis in mice. The British journal of nutrition. 2014;112(6):868-875. doi: 10.1017/S0007114514001792
41. Karlsson CL, Onnerfalt J, Xu J, Molin G, Ahrne S, Thorngren-Jerneck $\mathrm{K}$. The microbiota of the gut in preschool children with normal and excessive body weight. Obesity. 2012;20:2257-2261. doi: 10.1038/ oby.2012.110.

42. Million M, Angelakis E, Maraninchi M, Henry M, Giorgi R, Valero R et al. Correlation between body mass index and gut concentrations of Lactobacillus reuteri, Bifidobacterium animalis, Methanobrevibacter smithii and Escherichia coli. International Journal of Obesity. 2013:37(11):1460-1466. doi: 10.1038/ijo.2013.20

43. Peng X, Li S, Luo J, Wu X, Liu L. Effects of dietary fibers and their mixtures on short chain fatty acids and microbiota in mice guts. Food \& function. 2013;4(6):932-938. doi: 10.1039/c3fo60052a.

44. Geurts L, Everard A, le Ruyet P, Delzenne NM, Cani PD. Ripened dairy products differentially affect hepatic lipid content and adipose tissue oxidative stress markers in obese and type 2 diabetic mice. Journal 